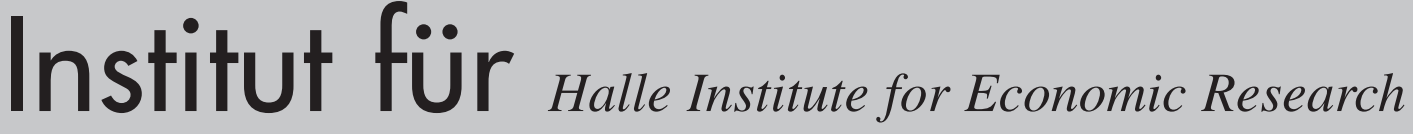 Wirtschaffsforschung Halle
}

Government Banking in Russia:

Magnitude and New Features

Andrei Vernikov

August 2011

No. 13

\section{IWH-Diskussionspapiere IWH Discussion Papers}


Government Banking in Russia:

Magnitude and New Features

\author{
Andrei Vernikov
}

August 2011

No. 13 
Author: Andrei Vernikov

Higher School of Economics (Moscow)

Faculty of Economics

Department of Banking

E-Mail: verand77777@gmail.com

Phone: +77295 90-2068

The responsibility for discussion papers lies solely with the individual authors. The views expressed herein do not necessarily represent those of the IWH. The papers represent preliminary work and are circulated to encourage discussion with the authors. Citation of the discussion papers should account for their provisional character; a revised version may be available directly from the authors.

Comments and suggestions on the methods and results presented are welcome.

IWH Discussion Papers are indexed in RePEc-Econpapers and in ECONIS.

Editor:

HALLE INSTITUTE FOR ECONOMIC RESEARCH - IWH

Prof Dr Dr h. c. Ulrich Blum (President), Dr Hubert Gabrisch (Research Director)

The IWH is a member of the Leibniz Association.

Address: $\quad$ Kleine Maerkerstrasse 8, D-06108 Halle (Saale), Germany

Postal Address: P.O. Box 1103 61, D-06017 Halle (Saale), Germany

Phone: $\quad+49(0) 3457753-60$

Fax: $\quad+49(0) 3457753-820$

Internet: $\quad$ http://www.iwh-halle.de 


\title{
Government Banking in Russia: Magnitude and New Features
}

\begin{abstract}
State-controlled banks are currently at the core of financial intermediation in Russia. This paper aims to assess the magnitude of government banking, and to reveal some of its special features and arrangements. We distinguish between directly and indirectly state-controlled banks and construct a set of bank-level statistical data covering the period between 2000 and 2011. By January 2011 the market share of state-controlled banks reached almost 54 percent of all bank assets, putting Russia in the same league with China and India and widening the gap from typical European emerging markets. We show that direct state ownership is gradually substituted by indirect ownership and control. It tends to be organized in corporate pyramids that dilute public property, take control away from government bodies, and underpin managerial opportunism. Statecontrolled banks blur the borderline between commercial banking and development banking. Dominance of public banks has a bearing on empirical studies whose results might suggest state-owned banks' greater (or lesser) efficiency or competitiveness compared to other forms of ownership. We tend to interpret such results as influenced by the choice of indicator, period of observations, sample selection, etc., in the absence of an equal playing field for all groups of players. We suggest that the government's planned retreat from the banking sector will involve non-core assets mainly, whereas control over core institutions will just become more subtle.
\end{abstract}

Keywords: Russia, banks, government, state-owned banks, public sector

JEL Classification: G21, G28, P31, P52

The author thanks Zuzana Fungáčová, Svetlana Kirdina, Iikka Korhonen, Laurent Weill, participants of the 11th Bi-Annual Conference of the European Association for Comparative Economic Studies (Tartu, Estonia), 6th Biennial Conference of the Czech Economic Society (Prague), 12th International Academic Conference on Economic and Social Development (Moscow), and at the seminar at Halle Institute for Economic Research. Research assistance rendered by Anna Anisimova is appreciated. 


\section{Staatliche Bankaktivitäten in Russland: Ausmaß und neue Merkmale}

\section{Zusammenfassung}

Staatlich kontrollierte Banken bilden den Kern der finanziellen Intermediation in Russland. Dieses Diskussionspapier zielt darauf ab, das Ausmaß der staatlichen Bankaktivitäten zu beurteilen und einige Besonderheiten sowie die aktuellen Regelungen aufzuzeigen. Wir unterscheiden zwischen direkt und indirekt kontrollierten Banken und konstruieren aus den für den Bankensektor spezifischen Daten einen Datensatz für die Periode von 2000 bis 2011. Danach erreichte der Marktanteil staatlich kontrollierter Banken im Januar 2011 fast 54 \% der Aktiva des gesamten Bankensektors. Damit findet sich Russland in einer Liga mit China und Indien wieder, während sich die Kluft zu den europäischen emerging markets vergrößerte. Wir zeigen, dass das direkte staatliche Eigentum allmählich durch indirekte Eigentumsformen und Kontrollen ersetzt wird. Damit verwischen staatlich kontrollierte Banken auch die Grenze zwischen Geschäfts- und Entwicklungsbanken. Die Dominanz der staatlichen Kontrolle hat auch einen Einfluss auf empirische Studien, deren Ergebnisse darauf hindeuten, dass eine staatseigene Bank im Vergleich zu anderen Formen des Bankeneigentums eine höhere (oder niedrigere) Effizienz und Wettbewerbsfähigkeit aufweist. Aufgrund einer fehlenden Vergleichsgruppe mit gleichen Wettbewerbsbedingungen für alle Gruppen von Spielern interpretieren wir diese Ergebnisse als beeinflusst durch die Wahl des Indikators, des Zeitraums der Beobachtungen sowie durch die Stichprobenauswahl. Schließlich wird deutlich, dass der von der Regierung geplante Rückzug aus dem Bankensektor im Wesentlichen die nicht zum Kerngeschäft gehörenden Vermögenswerte betreffen wird, während die Kontrolle der Kern-Institutionen nur subtilere Formen annehmen wird.

Schlagwörter: Russland, Banken, Regierung, staatliche Banken, öffentlicher Sektor JEL-Klassifikation: G21, G28, P31, P52 


\section{Introduction}

Since the time of the 1998 crisis the presence of the government as majority owner of commercial banks in Russia has increased steadily. By the end of 2008 the combined market share of state-controlled banks surpassed one-half of the country's total banking assets, sending into a decline genuine commercial banking based on private initiative. Was it a short-term effect of the financial crisis of 2008 or a natural systemic choice for essentially a non-market redistributive economy (Kirdina, 2004)? The question remains valid regardless of the recently-declared intention of the Russian government to start withdrawing from some of the core entities in industry and financial sector.

Government banking attracts the attention of academics. In a seminal and influential paper on political economy of government banking La Porta, López-de-Silanes and Shleifer (2002) reviewed the causes and consequences of direct state ownership of banks, especially in developing countries. A number of empirical studies have been devoted to comparative efficiency and competitiveness of state-controlled banks vis-à-vis other groups of banking market participants, namely domestic private and foreignowned banks (Barth, Caprio, Levine, 2000; Bonin, Hasan, Wachtel, 2005; Fries, Neven, Seabright, Taci, 2006; Fungáčová, Poghosyan, 2009; Anzoátegui, Martínez Pería, Melecky, 2010; Fungáčová, Solanko, Weill, 2010; Karas, Schoors, Weill, 2010). We also observe a renewed interest in re-testing by recent empirical data the macroeconomic effects of government ownership of banks. Andrianova, Demetriades and Shortland (2009) and Körner and Schnabel (2010) challenge the belief that the impact of government banking on financial development and economic growth in developing countries is homogeneous and negative (La Porta et al., 2002); they argue that the impact is actually heterogeneous depending on the quality of local institutions, starting level of development and other parameters, and can be neutral or even positive.

This paper revisits government ownership of banks in Russia by offering an alternative estimate of the share of public sector in the banking industry and discussing some of its special features, such as corporate pyramids and replacement of direct government ownership by less transparent schemes of indirect ownership and control. We also try to contribute to the interpretation of empirical results concerning state-owned banks' comparative efficiency and market position.

The rest of the paper is organized as follows. Section 2 assesses the magnitude of public sector in the Russian banking industry. Section 3 describes the replacement of direct government ownership by indirect ownership and control. Section 4 interprets the results of empirical studies on comparative performance of state-owned banks. Section 5 discusses cyclicality of state engagement and disengagement from the banking industry. Section 6 concludes. 


\section{Scope of Public Sector in Russian Banking}

In order to build a sample of state-controlled banks we screened individual firms for presence of public sector institutions among their shareholders. Information sources included statutory disclosure by banks and their parent companies, annual and quarterly reports, Central Bank of Russia (CBR) publications and website. Bank-level statistical data were borrowed from Interfax quarterly database of Russian banks (Interfax, 2010), Rozbizneskonsalting rankings (RBK, March 2011) and bank web-sites. Official sources do not break down companies by form of property in a way acceptable from a substantive viewpoint (Sprenger, 2010, p.68). Absence of governmental authorities among shareholders of record is sufficient legal ground to regard such a bank as nominally private. Analytical reports of the CBR do not specify which exactly institutions comprise 'state-controlled banks'. The legal status of bank equity stakes belonging to state-owned enterprises and banks is more blurred yet. All attributions with respect to form of ownership at individual banks were thus made by the author along with the principle of economic substance over legal form (funds of public origin should constitute at least one-half of bank's equity').

We distinguish two types of state-controlled banks 2 . In a directly-controlled institution government authorities at federal or sub-federal level directly own a controlling stake of shares. In an indirectly-controlled bank a controlling stake belongs to companies and banks whose equity is formed with public funds. State-controlled banks are listed in Table 1.

The three 'national champions' at the federal level (Sberbank, VTB and Rosselkhozbank) constitute the hard core of the public sector. After reaching its numerical peak of 46 in December 2009, our sample of state-controlled banks shrank by December 2010 to 40 institutions, out of which 17 banks were directly owned by the state and 23 were indirectly-owned (Table 2). To the latter category we attribute the offspring of 'state corporations'3 like ASV (deposit insurance agency) or Vneshekonombank (development bank), industrial companies like Gazprom, Rosneft, RZhD (Russian Railways) or Alro$s a$, and federally-owned banks such as $V T B$, and indirectly state-controlled banks like Gazprombank, TransKreditBank, VBRR, or Bank Moskvy.

1 We regard 50 percent of equity as the threshold for corporate control in view of Russia's controversial practice in the field of corporate governance, although more liberal criteria of control have been used in the literature. La Porta, López-de-Silanes and Shleifer (2002) would recognize a bank as 'government-owned' if government holds at least 20 percent of equity but acts as the single largest shareholder. OECD (2005) suggests that significant state control starts at the level of 10 percent of voting rights in the company.

2 On technically legal grounds the widespread notion of 'state-owned' enterprises and banks seems imprecise. A joint-stock company cannot be 'owned'; its shares can. The government may own up to 100 percent of a bank's equity but cannot claim to 'own' the institution as a whole. The author thanks Suren Gomtsyan for pointing this out. The concept of 'state-owned' appears less appropriate yet where the government exercises control through significant minority ownership, as provided by the OECD definition of state-owned enterprises (Sprenger, 2010, 64).

3 'State corporations' are entities established and governed individually by a respective federal law. 'State corporations' are neither state bodies nor corporations (joint-stock companies) in the conventional sense because by law they are, weirdly, non-profit entities. 
Table 1:

State-controlled banks in Russia, January 2011

\begin{tabular}{|c|c|c|c|c|c|}
\hline Reg.\# & Bank name & Region $^{\mathrm{a}}$ & $\begin{array}{l}\text { Direct/ } \\
\text { indirect }\end{array}$ & Who controls & $\begin{array}{l}\text { Assets, } \\
\text { RUB bn }\end{array}$ \\
\hline 354 & Gazprombank & Moscow & $\mathrm{I}$ & Gazprom, Gazfond & 1,812 \\
\hline 439 & VTB Severo-Zapad & St.Petersburg & I & VTB & 254 \\
\hline 459 & Tarkhany & Penza & $\mathrm{I}$ & $\mathrm{ASV}^{\mathrm{b}}$ & 8 \\
\hline 708 & Bank Kazani & Tatarstan & I & Kazan municipality & 5 \\
\hline 843 & Dalnevostochniy & Primorye & $\mathrm{I}$ & VBRR & 28 \\
\hline 918 & Zapsibkombank & Tyumen & $\mathrm{D}$ & $\begin{array}{l}\text { Tyumen + Yamalo-Nenetsk } \\
\text { regional administrations }\end{array}$ & 65 \\
\hline 1000 & VTB & St.Petersburg & $\mathrm{D}$ & Federal government & 2,732 \\
\hline 1019 & Potencial-Bank & Samara & $\mathrm{I}$ & ASV & 6 \\
\hline 1088 & MAK-Bank & Moscow & $\mathrm{I}$ & Alrosa & 7 \\
\hline 1280 & Chuvashkreditprombank & Chuvashiya & $\mathrm{D}$ & Regional administration & 4 \\
\hline 1399 & Elita & Kaluga & $\mathrm{D}$ & Regional administration & 1 \\
\hline 1470 & Svyaz-Bank & Moscow & $\mathrm{I}$ & $\mathrm{VEB}^{\mathrm{c}}$ & 181 \\
\hline 1481 & Sberbank & Moscow & $\mathrm{D}$ & Central Bank of Russia & 8,888 \\
\hline 1623 & VTB-24 & Moscow & $\mathrm{I}$ & VTB & 923 \\
\hline 1911 & KIT Finance & St.Petersburg & $\mathrm{I}$ & Russian Railways & 115 \\
\hline 1942 & Globex & Moscow & $\mathrm{I}$ & VEB & 111 \\
\hline 2015 & Sibsotsbank & Altay & $\mathrm{D}$ & Regional administration & 4 \\
\hline 2142 & Transkreditbank & Moscow & $\mathrm{I}$ & Russian Railways & 378 \\
\hline 2274 & Noyabrskneftekombank & Tyumen & $\mathrm{I}$ & Gazprombank & 3 \\
\hline 2307 & Soyuz & Moscow & I & ASV & 76 \\
\hline 2312 & Rossiyskiy kapital & Moscow & $\mathrm{I}$ & ASV & 38 \\
\hline 2403 & GPB-Ipoteka & Moscow & I & $\begin{array}{l}\text { Gazprombank, } \\
\text { Gazpromexport }\end{array}$ & 18 \\
\hline 2584 & Kredit-Ural & Chelyabinsk & $\mathrm{I}$ & Gazprombank & 21 \\
\hline 2590 & Ak Bars & Tatarstan & $\mathrm{D}$ & Regional administration & 231 \\
\hline 2602 & Almazergienbank & Yakutia & $\mathrm{D}$ & Regional administration & 11 \\
\hline 2748 & Bank Moskvy & Moscow & $\mathrm{D}$ & Moscow city government & 923 \\
\hline 2790 & Roseximbank & Moscow & $\mathrm{I}$ & VEB & 8 \\
\hline 2802 & Yoshkar-Ola & Mariy El & $\mathrm{D}$ & Regional administration & 1 \\
\hline 2816 & Severgazbank & Vologda & $\mathrm{I}$ & Gazprombank & 25 \\
\hline 2863 & Mosvodokanalbank & Moscow & $\mathrm{I}$ & Bank Moskvy & 3 \\
\hline 2898 & Kubanskiy universalny bank & Krasnodar & $\mathrm{D}$ & Krasnodar municipality & 1 \\
\hline 3042 & Sibirgazbank & Tyumen & $\mathrm{I}$ & Gazprombank & 4 \\
\hline 3099 & $\begin{array}{l}\text { Rossiyskaya finansovaya } \\
\text { korporaciya }\end{array}$ & Moscow & $\mathrm{D}$ & Federal government & 0 \\
\hline 3269 & Orenburg & Orenburg & $\mathrm{D}$ & Regional administration & 9 \\
\hline 3287 & VBRR & Moscow & $\mathrm{I}$ & Rosneft & 60 \\
\hline 3340 & Rossiyskiy bank razvitiya & Moscow & $\mathrm{I}$ & VEB & 90 \\
\hline 3344 & $\begin{array}{l}\text { Moskovskoe ipotechnoe } \\
\text { agentstvo }\end{array}$ & Moscow & $\mathrm{D}$ & Moscow city government & 11 \\
\hline 3349 & Rosselkhozbank & Moscow & $\mathrm{D}$ & Federal government & 1,070 \\
\hline 3360 & Krayinvestbank & Krasnodar & $\mathrm{D}$ & Regional administration & 23 \\
\hline 3466 & Nacionalny kliringoviy centr & Moscow & $\mathrm{I}$ & MICEX & 11 \\
\hline
\end{tabular}

${ }^{\mathrm{a}}$ Place of registration. $-{ }^{\mathrm{b}}$ Deposit Insurance Agency. $-{ }^{\mathrm{c}}$ Vneshekonombank.

Source: Bank Data. 
Table 2:

Breakdown of state-controlled banks

\begin{tabular}{lllll}
\hline \multirow{2}{*}{ Who controls over 50\% of the bank equity } & \multicolumn{3}{l}{ Number of banks $^{\mathrm{a}}$} \\
\cline { 2 - 5 } & 2000 & 2007 & 2009 & 2010 \\
\hline Directly state-controlled banks, of which by: & $\mathbf{1 7}$ & $\mathbf{1 7}$ & $\mathbf{1 9}$ & $\mathbf{1 7}$ \\
$\quad$ federal executive authorities or the Central Bank of Russia & 6 & 4 & 4 & 4 \\
$\quad$ regional authorities and federal cities' governments & 10 & 10 & 12 & 11 \\
$\quad$ municipal authorities & 1 & 3 & 3 & 2 \\
Indirectly state-controlled banks, of which by: & $\mathbf{1 8}$ & $\mathbf{2 2}$ & $\mathbf{2 7}$ & $\mathbf{2 3}$ \\
'state corporations'(ASV ${ }^{\mathrm{b}}$ and VEB') & 0 & 2 & 8 & 8 \\
state-owned banks & 11 & 13 & 12 & 9 \\
state-owned companies other than banks & 7 & 7 & 7 & 6 \\
\hline Total & $\mathbf{3 5}$ & $\mathbf{3 9}$ & $\mathbf{4 6}$ & $\mathbf{4 0}$
\end{tabular}

${ }^{\mathrm{a}}$ By year end. $-{ }^{\mathrm{b}}$ Deposit Insurance Agency. $-{ }^{\mathrm{c}}$ Vneshekonombank.

Source: Own calculation; Bank Data.

According to our calculation, by the end of 2010 combined assets of state-controlled banks4 grew to RUB 18.2 trillion. Their aggregate market share reached its peak of 54.7 percent in 2009 before slightly contracting to 53.7 percent by the end of 2010, as depicted on Fig. 1 with a breakdown between types of banks5. The above estimates appear on the high side as compared to the an official central bank report that put statecontrolled banks' share of total bank assets at 45.8 percent by the beginning of 2011 (CBR, 2011, p.21). That was in between our figures of 41.3 percent referring to narrowly-defined state property (federal, regional and municipal authorities) and 53.7 percent in the broad definition (including banks indirectly owned and controlled by the state). We thus attribute the discrepancy to different coverage of the latter category. 6

State-controlled banks are now active in all or most of the market segments, and not only in collecting household deposits. At the end of 2009 they held 63 percent of the total corporate loans portfolio and 52 percent of bank loans to private individuals (Fig.2).

4 Assets of banks where state participation exceeds 50 percent are counted fully.

5 Policy lenders without a banking license are left beyond the scope of analysis in this paper because banking statistics does not capture their lending operations. The figure on market share of statecontrolled banks does not include the commercial loans portfolio (mainly corporate lending and preexport finance) of Vneshekonombank itself, although we do include the figures of its subsidiaries, Svyaz-Bank and Globex-Bank. We estimate that on a consolidated basis the commercial loans portfolio of Vneshekonombank has reached 2 percent of Russia's total bank loans (Vneshekonombank, 2010, p.11).

6 Probably in the 2010 report for the first time CBR experts started including among 'state-controlled banks' those controlled by 'state corporations', and not only by federal, regional or municipal authorities. 
Figure 1:

Market share of state-controlled banks in Russia (percent of total assets, year end)

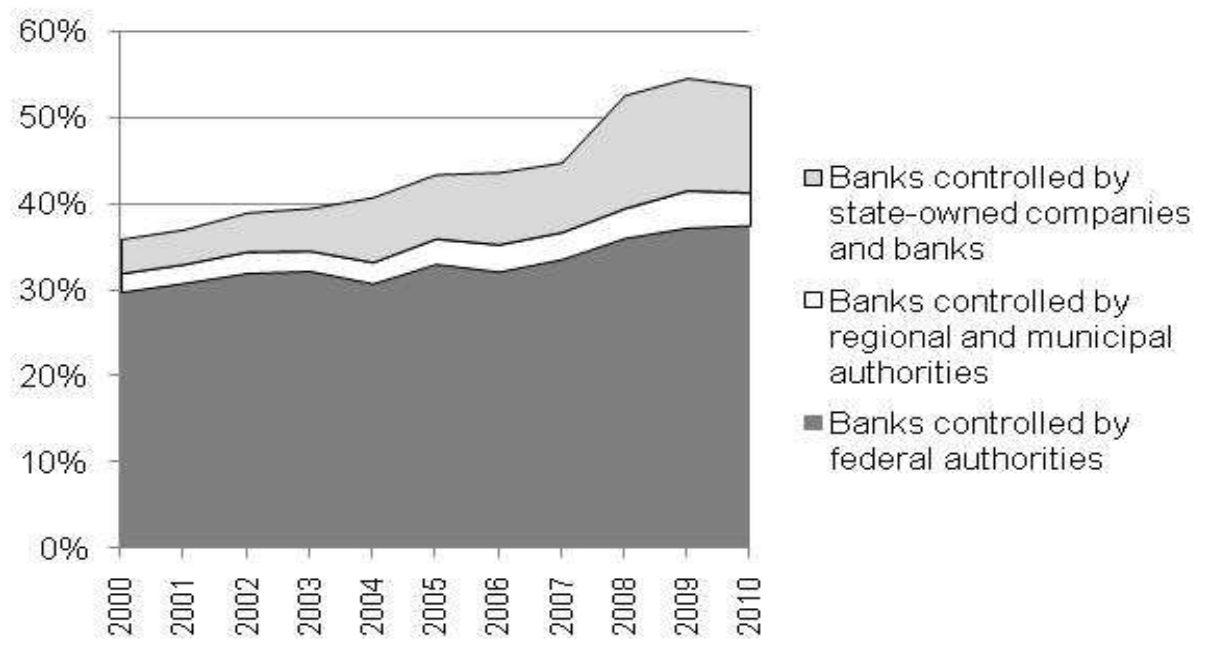

Source: Author's calculations based on Bank Data, CBR, RBC and Interfax.

Figure 2:

Market share of state-controlled banks in selected market segments (year end data for 2006-2009; data by March 31 of the following year for 2000-2005)

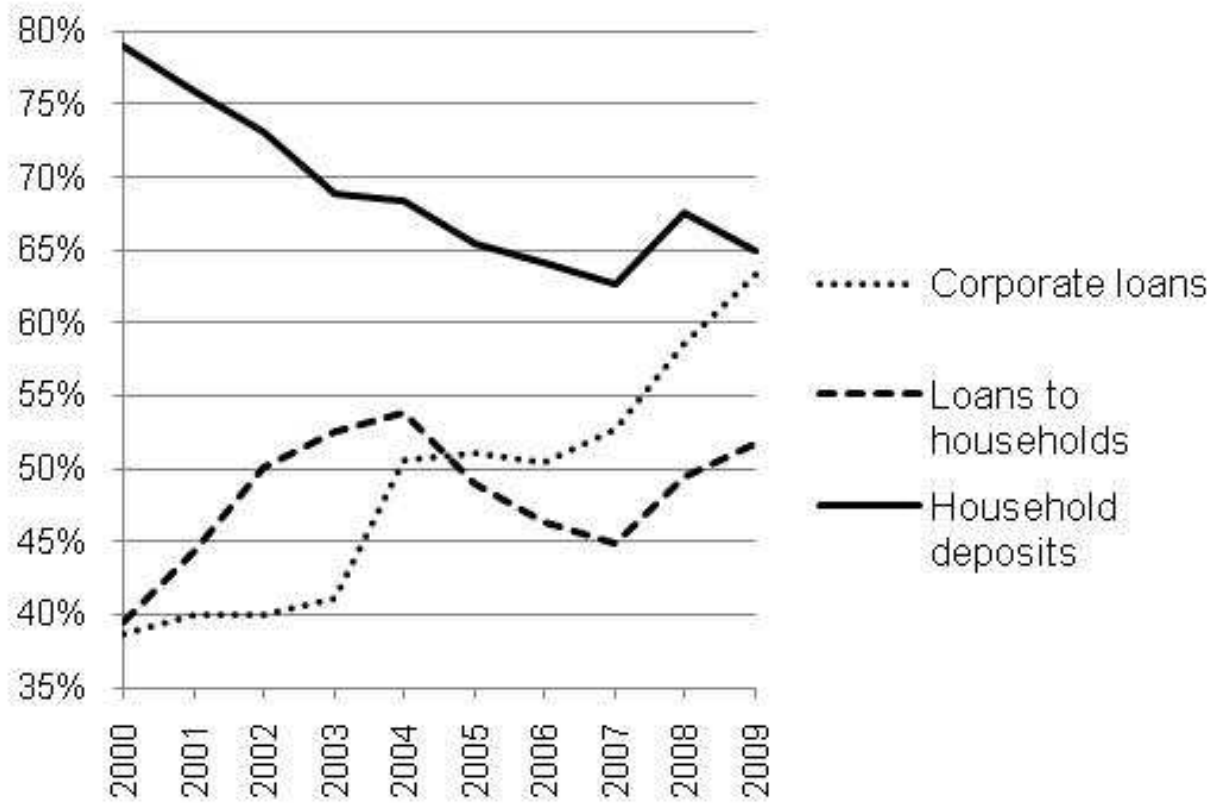

Source: Own calculations based on Bank Data, CBR and Interfax (2010). 
From the perspective of government presence in the banking industry Russia diverges markedly from the general pattern of transition economies in Central and Eastern Europe; only Belarus is ahead of it (Fig.3).

Figure 3:

Market share of state-controlled banks (percentage of total assets, yearend)

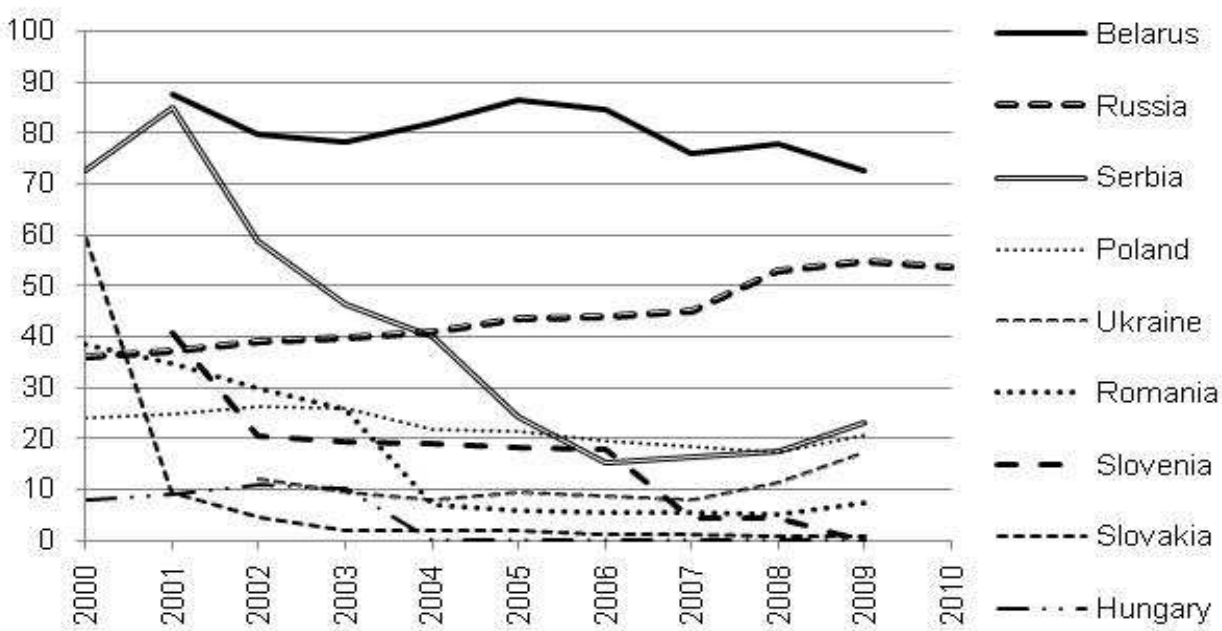

Sources: For Russia own calculations based on bank data; for other countries Raiffeisenbank (2006; 2010).

The difference between Russia and Central and Eastern European economies may be the direction of transition and not merely its pace. The majority of European transition countries moved away from government banking towards a system driven by private, predominantly foreign, capital. Russian banking system apparently evolves in a quite different direction. The sheer size of public sector in banking (54 percent) puts Russia in the same league with India (around 75 percent) and China (over 90 percent) (The Economist, 395(8682), A special report on emerging markets, May 15 ${ }^{\text {th }}, 2010$, pp.10-12; Reserve Bank of India). True privatization of leading financial institutions has been carefully avoided. Industrial policy consists in growing 'national champions' within the public sector, modernizing them to the extent possible and supporting their expansion including overseas. China pursues much the same policy.

Upward trend in the market share of state-controlled banks began in 1999, i.e. years before the financial crisis of 2008-9. Public sector expansion was driven by a combination of organic growth and takeovers of private banks. According to our calculation, from 1Q2000 through 1Q2011 state-controlled banks have been growing by 62 percent a year (assets in nominal terms in national currency, not-weighted average), whereas all other Russian banks grew by 29 percent a year. Since the outbreak of the financial crisis in 2008 public banks strengthened their market position due to liquidity support and equity contributions from the government, whereas other groups of market participants (foreign-controlled banks and private national banks) saw their balance sheets shrink more significantly. 
Takeovers of private banks by public ones were another driver of public sector expansion. First takeovers happened back in 2004 and 2005 (Vneshtorgbank took over the failed Guta-Bank and the viable Promstroybank). The 2008 crisis enhanced the transfer of weak private banks under control of the state represented by deposit insurance agency $A S V$, the development bank Vneshekonombank, Russian Railways, Gazprom group companies and banks.

Fig.4 depicts crowding out of domestic private sector by public sector and, to a lesser extent, foreign bank subsidiaries. In 2010 the expansion of the public sector came to a halt and was partly reversed as a product of private sector recovery, state withdrawal from several non-core institutions, and asset-stripping at state-controlled banks (more detail in Section 4).

Figure 4:

Crowding out of domestic private banks (shares of total bank assets, yearend)

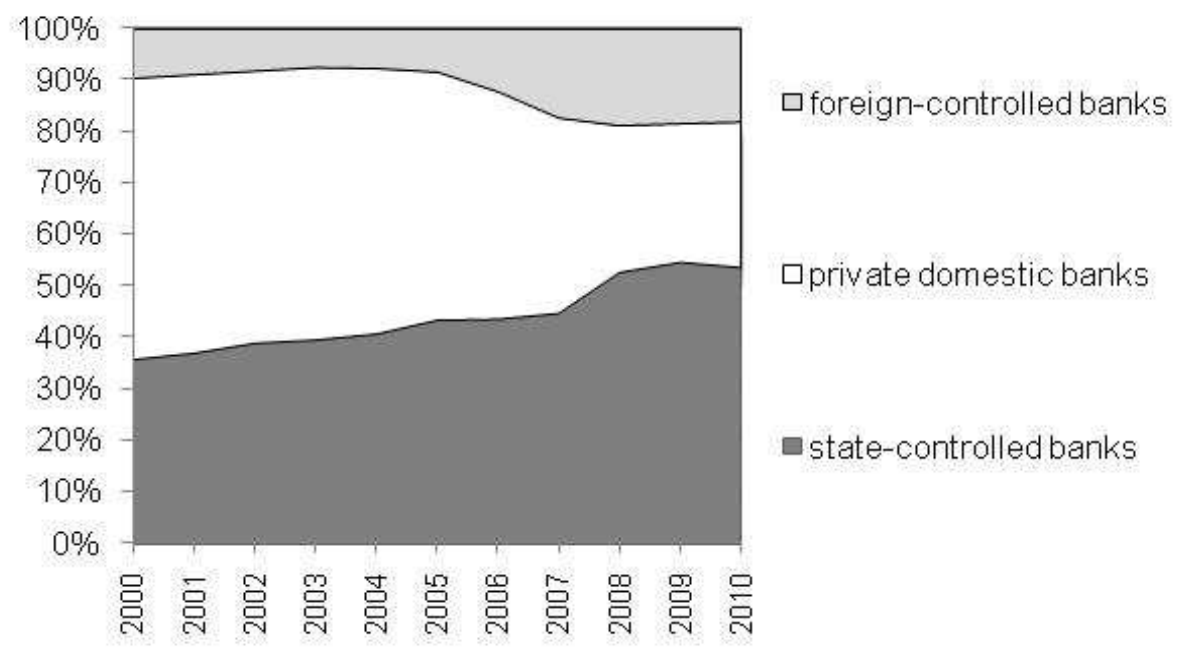

Source: Own calculations; Bank Data; RBK (2011); Interfax (2010).

\section{Direct vs. Indirect Government Ownership and Control}

While direct government ownership offers a bank a more solid and secure market position, it implies costs. Direct reporting to the government enables interference by civil servants and politicians pursuing non-economic goals with disregard to corporate interests of the bank. Banks directly owned by the state are bound by general public sector rules and regulations that may be time-consuming and cumbersome. Core state-owned banks have to perform peculiar policy functions on behalf of the government and central bank (e.g., allocating liquidity among banks in the lower tier; acquiring and holding on the balance sheet non-core industrial assets; making long-term investment available to 'systemically-important' enterprises and 'strategic projects', including sport and con- 
gress facilities; providing first-aid funds to companies and regions hit by natural or technological disasters).

Since the start of observations (January 2001) we see within the public sector a gradually increasing share of banks indirectly controlled by the state via state-owned entities and 'state corporations'. That share now stands at roughly one-fourth (Fig.5).

Figure 5:

Restructuring within the public sector of banking (percent of total assets of statecontrolled banks, year end)

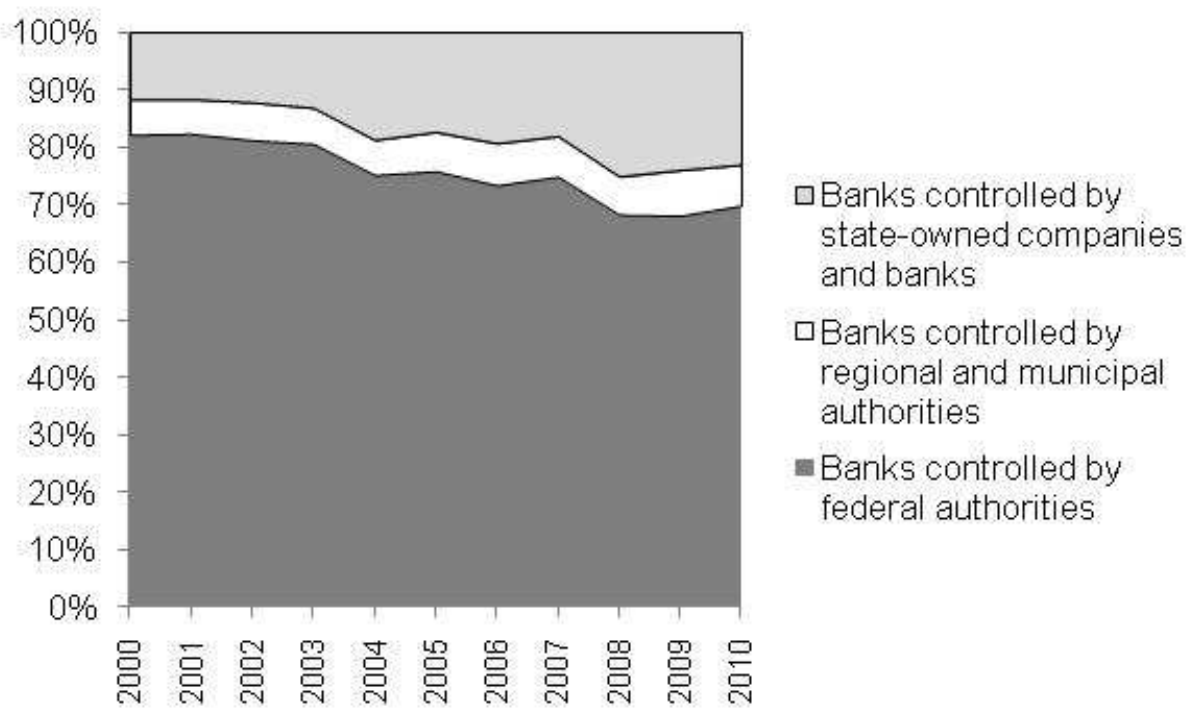

Source: Own calculations; Bank Data; RBK (2011); Interfax (2010).

In 2007 the government transferred two of its banks (Rossiyskiy bank razvitiya and Roseximbank) from federal ownership into the property of Vneshekonombank. After 2008 the government assigned the task of taking over the failing private banks to 'state corporations' ( $A S V$ and Vneshekonombank) and state-owned enterprises, and funded the rescue operations. Unlike Fidrmuc and Süss (2011) who regard bank takeovers by $A S V$ and Vneshekonombank as direct government bailouts, we think that those cases rather fit the pattern of indirect state control.

Indirect state ownership of banks tends to be organized in the form of corporate pyramids, i.e. ownership structures with several intermediate layers of corporate control and a large state-owned enterprise or bank at the top. For example, the federal government is separated by 3 intermediate layers from Severgazbank, a subsidiary of Gazprombank.

There might be a variety of reasons why an owner would build a corporate pyramid. From the perspective of the government, choice of indirect, instead of direct, control may stem from inability to efficiently manage and control a big number of banks by traditional methods of state governance. Other relatively benign motivations are to overcome property right and financing constraints and bureaucratic hurdles, decentralize de- 
cision rights while preserving control, gain in terms of flexibility of management, governance and efficiency. Indirect public ownership opens preferential access to public funds while allowing a higher degree of immunity from government interference (Fan, Wong, Zhang, 2005; Okhmatovskiy, 2009). The degree of political interference in such banks is lower, allowing them to take business decisions fast and to pursue essentially profit-oriented policies. Looking at data for 2001-2003, Okhmatovskiy (2009) found that in terms of profitability proxied by return on assets the banks with ties to stateowned enterprises had an advantage over banks directly controlled by the government.

On the other hand, corporate pyramids separate control from ownership. Gazprombank, Russia's $3^{\text {rd }}$ largest bank initially was under direct control of OAO Gazprom. Now the stake of Gazprom fell to 41.73 percent, and Gazprombank's majority shareholder of record is Gazfond, the Gazprom's pension fund run by Lider company influenced by private shareholders of Bank Rossiya. Likewise, Moscow city government used to control fully Bank Moskvy, Russia's $5^{\text {th }}$ largest financial institution, from its inception in 1995, but after a chain of seemingly innocent corporate actions direct control slipped away from the government, leaving the city of Moscow with just $48.11 \%$ percent of equity.

Each additional tier of a corporate pyramid weakens public control and scrutiny over the use of public funds. In addition, indirectly state-owned banks sometimes recur to circular structures of corporate ownership and control. 6.98 percent of Gazprombank shares belong to "OOO Novfintekh", Gazprombank's subsidiary company. Bank Moskvy and Stolichnaya strakhovaya gruppa own each other's shares. Mutual ownership of shares is usually employed as a defense instrument against corporate raiders, but its usage in the public sector might seem unnatural. It probably reflects the intention of bank insiders to entrench against outside shareholders or to prepare ground for appropriation of assets.

Indirect state ownership is preferred by influential insiders of respective banks because it reduces their accountability and allows running those banks like their private property. Indirect ownership often leads to dilution of majority stakes, tacit appropriation of bank equity and other examples of opportunistic behavior by managers. Bank Moskvy is a clear illustration of corporate governance failure resulting from loss of direct control over a state-owned bank's activities. The previous mayor of the City of Moscow entrusted the bank to its then CEO who found himself beyond any control. The CEO became an important minority shareholder of the bank controlling up to 25 percent of equity directly and otherwise. In 2011 new top-managers of Bank Moskvy discovered that previous management team had lent over RUB 200 bn to related companies. The combined value of such loans exceeded 150 percent of the bank's equity (while according to international standards anything exceeding 25 percent is deemed imprudent). Recovery of those loans is highly questionable. In total the rehabilitation of Bank Moskvy may require RUB 295 bn of public funds coming from the CBR via the deposit insurance agency (Kommersant, 05.07.2011). 


\section{$4 \quad$ Are State-controlled Banks Different?}

Some authors argue that form of ownership is irrelevant to performance and what matters is quality of legal system, management, corporate governance etc. However, empirical studies using form of ownership as explanatory variable find that financial performance and market behavior of state-controlled banks differ from those of private as well as foreign-controlled banks. The sign of the difference is unclear, though.

Karas et al. (2010) found that in Russia domestic public banks are no less efficient than private ones. That surprising prediction was later validated by banking statistics: by 2010 state-controlled banks (in Central Bank of Russia definition) were ahead all other groups of domestic banks in terms of profitability (Table 3).

Table 3:

Comparative profitability of banks in Russia

\begin{tabular}{|l|c|c|c|c|}
\hline \multirow{2}{*}{} & \multicolumn{2}{|c|}{$\begin{array}{c}\text { Return on assets, } \\
\text { percent }\end{array}$} & \multicolumn{2}{c|}{$\begin{array}{c}\text { Return on equity, } \\
\text { percent }\end{array}$} \\
\cline { 2 - 5 } & 2009 & 2010 & 2009 & 2010 \\
\hline All banks & $\mathbf{0 . 7}$ & $\mathbf{1 . 9}$ & $\mathbf{4 . 9}$ & $\mathbf{1 2 . 5}$ \\
\hline State-controlled banks ${ }^{\mathrm{a}}$ & 0.7 & 2.4 & 4.3 & 14.8 \\
\hline Foreign-controlled banks & 1.1 & 2.1 & 8.3 & 14.5 \\
\hline Large private domestic banks & 0.4 & 1.1 & 3.2 & 8.4 \\
\hline Small and medium-sized banks, Moscow & 1.2 & 1.4 & 5.2 & 6.7 \\
\hline Small and medium-sized banks, other regions & 1.1 & 1.5 & 6.2 & 9.8 \\
\hline
\end{tabular}

${ }^{a}$ CBR definition, i.e. partial coverage of indirectly state-controlled banks.

Source: CBR, 2011, pp.25-26

Table 4 offers descriptive statistics for our sample of state-controlled banks. While state-controlled banks tend to be much larger than other Russian banks, their operational characteristics, and especially the cost-income ratio, are not necessarily better.

Fungáčová, Solanko and Weill (2010) found no greater market power for Russian statecontrolled banks over 2001-7. The finding of presumably lower market power of public banks stems from another empirical result, namely that state-owned banks operate with a narrower interest margin. Fungáčová and Poghosyan (2009) analyze interest margin determinants with a particular emphasis on the bank ownership structure and argue that state-controlled banks do not seem to take credit risk into account in their pricing strategy. By contrast, Anzoátegui, Martínez Pería and Melecky (2010) argue that the top 20 Russian banks and state-owned banks seem to be able to exert more market power than the smaller banks and privately-owned institutions. 
Table 4:

Descriptive statistics of state-controlled banks, 31.12.2009

\begin{tabular}{|l|c|c|c|c|c|c|}
\hline & \multicolumn{2}{|c|}{$\begin{array}{c}\text { Directly-controlled } \\
\text { by state }\end{array}$} & \multicolumn{2}{c|}{$\begin{array}{c}\text { Indirectly- } \\
\text { controlled by state }\end{array}$} & \multicolumn{2}{c|}{$\begin{array}{c}\text { All other } \\
\text { Russian banks }\end{array}$} \\
\cline { 2 - 7 } & Mean & S.D. & Mean & S.D. & Mean & S.D. \\
\hline Number of banks & 17 & - & 27 & - & 1,012 & - \\
\hline Assets (RUB bn) & 628 & 1,687 & 156 & 337 & 12 & 46 \\
\hline Equity (RUB bn) & 89 & 227 & 14 & 27 & 1.6 & 5.4 \\
\hline $\begin{array}{l}\text { Loans to non-financial companies/ } \\
\text { Total assets, percent }\end{array}$ & 41 & 15 & 35 & 21 & 34 & 21 \\
\hline Equity / Total assets, percent & 20 & 12 & 13 & 8 & 26 & 18 \\
\hline ROA, percent & 3 & 1 & 2 & 3 & 3 & 6 \\
\hline ROE, percent & 16 & 11 & 21 & 37 & 15 & 24 \\
\hline Cost / Income, percent & 52 & 20 & 54 & 23 & 39 & 28 \\
\hline $\begin{array}{l}\text { Loan-loss provisions/ } \\
\text { Total loans, percent }\end{array}$ & 7 & 3 & 22 & 44 & 13 & 15 \\
\hline
\end{tabular}

Source: own calculations based on data from Interfax (2010); RBK (2011); CBR (2011)

One important feature is execution of social, geopolitical or whatever other noneconomic tasks by state-owned banks on behalf of the government. Currently the government is responsible for more than two-thirds of all investment in industry and infrastructure (Lebedev, Sivakov, 2011) and most of that investment is channeled through state-controlled banks. The government's core banks (Sberbank, VTB, Rosselkhozbank and - to a lesser extent - Gazprombank) are pushed to develop policy lending and build a portfolio of policy-motivated assets (loans, equities and industrial assets) unusual for commercial banks.

An alternative explanation to seemingly higher profitability of state-owned banks is that financial data reported by them is less reliable than those reported by private and especially foreign-owned banks. Until 2011 financial statements of Bank Moskvy did not disclose the magnitude of lending to related companies, so inadequately low level of provisioning allowed the bank to report substantial 'profits' instead of a huge gap in the balance sheet. Strangely, external auditors overlooked that. This episode casts serious doubt on the quality of financial reporting at other large state-owned banks.

Whereas lending and pricing decisions of state-owned banks can deviate from economic rationality, lending on behalf of the government does not necessarily imply inferior revenue performance of public banks compared to private peers. A substantial share of profits earned by state-controlled banks may in essence represent rent coming from oligopoly position, fulfillment of public procurement, state backing, administrativelyimposed preferences, etc. Profitability is thus an improper indicator of relative performance in an economy with a blurred borderline between commercial banking and development banking and absence of a level playing field for all players. We think that if players with the largest market shares are basically non-market-type entities who by de- 
finition cannot go bankrupt thanks to soft budget constraint, then standard methodology of empirical industrial organization might be less relevant for modeling bank behavior.

One more possible explanation to lower average interest rates charged by public banks may be related to corruption. Sub-market lending rates can be partly offset by kickbacks paid by private borrowers to managers of state-owned banks, thus maintaining the total cost of borrowing at market-average.

\section{The State Engagement/Disengagement Cycle}

Since 1980s, state participation in the banking industry has followed a cycle of disengagement and re-engagement. After several decades of state monopoly on banking, a big-time state withdrawal started in the early-1990s. Unlike in CEE countries, in Russia banks were not subject to an organized privatization. Schoors (2002) features the pilfer of state-owned banks in 1990-92 as 'decentralized spontaneous privatization'. Top managers and other insiders tacitly appropriated substantial banking assets and the physical infrastructure of hundreds of spetsbanki local branches. At the beginning of 1994, 609 banks, or 29.8 percent of the 2,041 registered banks were successors of the former Soviet system of Gosbank (State Bank) and its affiliated spetsbanki (Promstroybank, Zhilsotsbank, Agroprombank and Vneshekonombank). Of those 609 banks, 42.7 percent were off-shoots from Agroprombank, 28.2 percent from Promstroybank and 20.2 percent from Zhilsotsbank (Schoors, 2002). A large proportion of former state banks did not survive financial turmoil of 1995, 1998-99, 2004 and 2008-09 due to mismanagement, incompetence, fraud, asset stripping etc.

After the 1998 financial crisis the government started a gradual but consistent reengagement with the banking industry. As shown in Section 2, the number of statecontrolled banks and their combined market share grew continuously for more than decade, and particularly in 2008-9. Unlike in some mature market economies, the de facto re-nationalization of banks in Russia did not envisage a clear exit strategy.

By 2010 the number of banks under state control by far exceeded the number that the government can run efficiently. Those banks' fields of activity and branch networks overlap7. Public funds worth hundreds of billions of rubles have been pumped into state-controlled banks. Sberbank received RUB 500 bn in 2009 as a subordinated loan; $V T B$ received RUB 630 bn since the outbreak of the crisis (Vedomosti, 01.07.2011, p.1). Now is high time for bank insiders and affiliated parties to try appropriating those funds

7 Rosselkhozbank (Russian Agricultural Bank) was meant to focus on servicing agricultural producers and rural citizens. Nevertheless in 2011 the share of urban citizens surpassed 25 percent of the bank's retail loans portfolio (Vedomosti, 05.07.2011). It reflects duplication of networks of statecontrolled banks operating in the same territory. 
under the aegis of 'privatization'. A favorable macroeconomic environment together with severe non-oil budget deficit triggers a new wave of public assets disposals within the eternal cycle of state engagement / withdrawal.

In 2010 both the number of state-controlled banks and their market share dropped from previous year's record levels. The government started withdrawing from second- and third-tier banks it came to control directly or indirectly. This disengagement is arranged in the usual opaque way. Insiders and operators with good political connections are set to benefit from it. One case is Sobinbank whose rescue was financed by public funds and executed by Gazenergoprombank, a member of Gazprom group. In 2010 both $G a-$ zenergoprombank and Sobinbank were 'privatized' for an undisclosed amount to a politically well-connected operator, Bank Rossiya of St.-Petersburg. A similar case is Bank Petrovsky: after a very expensive bailout by the deposit insurance agency $(A S V)$ it was sold at an unknown price to FK Otkrytie, a private financial group. One more case: the government of Khanty-Mansiysk region sold control of Bank Khanty-Mansiysky to a private Nomos-Bank, and with it went the control over a subsidiary called Novosibirsky municipalny bank. The terms were not disclosed.

In pursuit of a second 'national champion' position (after Sberbank) VTB bank gradually takes over and consolidates two other state-controlled banks, Bank Moskvy and Transkreditbank. Control over Transkreditbank will thus pass from one public sector entity (OAO RZhD - Russian Railways) to another (VTB), preserving indirect public ownership and control over the bank (Fig.6). As far as Bank Moskvy is concerned, its planned consolidation into $V T B$ group will actually complicate ownership structure: direct public control of the government of the city of Moscow will be replaced by indirect ownership of federal authorities via VTB bank (Fig.7).

Figure 6.

Envisaged ownership change involving Transkreditbank

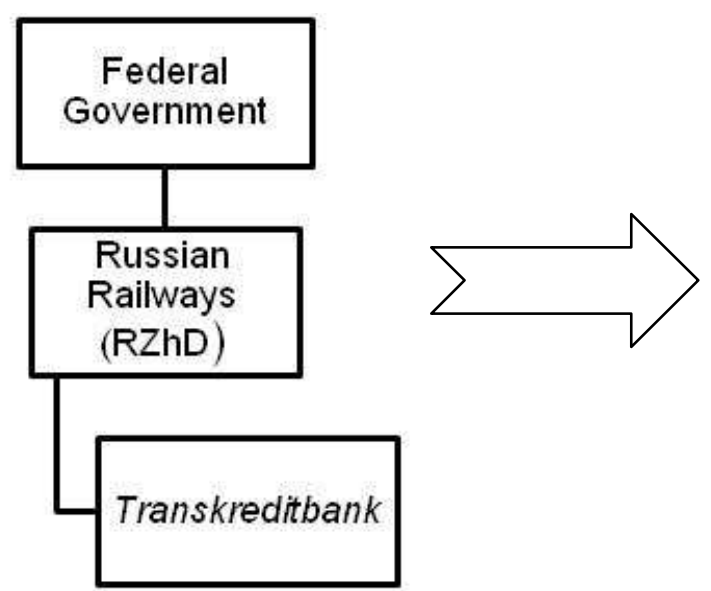

(a) before

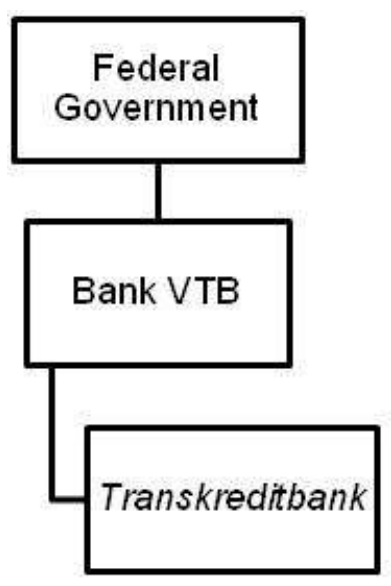

(b) after 
Figure 7.

Envisaged ownership change involving Bank Moskvy

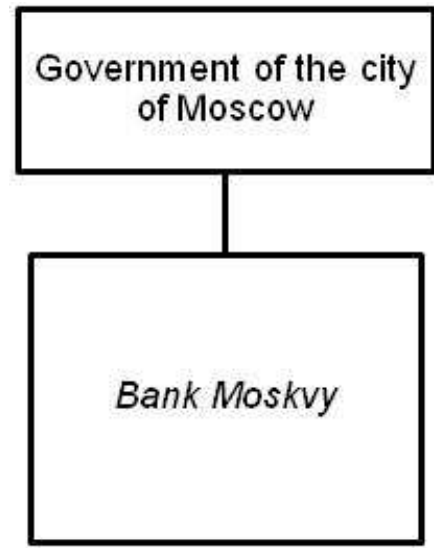

(a) before

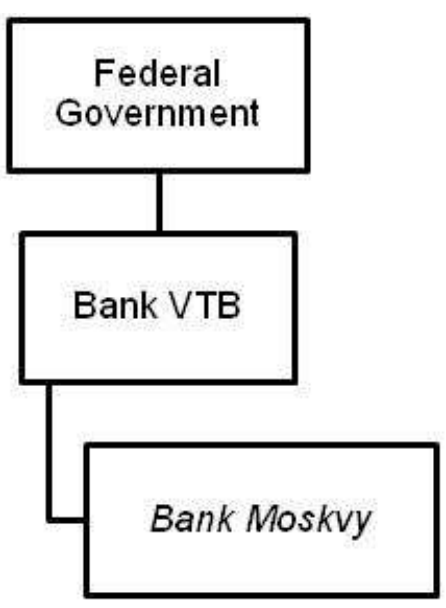

(b) after

More state divestments will follow. Vneshekonombank looks for a strategic investment partner to launch a post bank on the platform of Svyaz-Bank that it currently controls. It also considers selling Globex-Bank into which RUB 80 billion of public funds were sunk.

Impaired assets worth hundreds of billions of rubles have been written off or transferred from balance sheets of state-owned banks to their subsidiary companies (e.g. SberbankKapital, the Sberbank subsidiary) that are outside public scrutiny and disclose very little, if any, financial information. Statistically this process looks like market share reduction of state-owned banks.

The drive to divest grew stronger by June 2011 when the authorities signaled readiness to reduce their stake in some of the core institutions, e.g. VTB, below control level or even down to zero (Gazeta.ru, 17.06.2011, http://www.gazeta.ru/financial/2011/06/17/3665589.shtml), something that had been firmly denied just a year prior to that. Vested interests inside respective banks are very likely to benefit from government withdrawal. Indirectly state-owned banks are particularly prone to insider appropriation, and in the years to come the government will probably lose any control over several of them in favor of those bank top managers and current minority shareholders. A good example of a rigged 'privatization' was the management buy-out of Russian Commercial Bank, the VTB subsidiary in Cyprus, for a price lower than the intermediate dividend for $2 \mathrm{H} 2009$ that new shareholders received shortly after the transaction.

Not every ownership change in a state-controlled bank qualifies for the term 'privatization', so in some well-advertised cases one only sees an imitation of privatization. If a 
market placement of minority stakes at Sberbank or VTB does not affect control, so there is no reason to call them privatization. If it does affect control, one has to look at the capital structure. As long as the government remains the largest single shareholder (other shareholders being portfolio and retail investors) it will be able control the management and the main financial flows. Nominal presence of external investors will create value for all shareholders while the bank's policy will still be driven by the authorities 8 . After the government has learned how to use corporate governance mechanisms (boards of directors, non-executive directors, committees, external audit, etc.) nothing actually impedes from divesting from the control stake even in core banks. The identity of substantial minority shareholders matters. There is a tendency to bring in affiliated parties or other public sector institutions, including foreign ones such as sovereign funds from China (Gazeta.ru, 24.06.11, http://www.gazeta.ru/financial/2011/06/24/3674449.shtml) or the Gulf or Southeast Asia.

In a futile attempt to avoid duplication of networks the government might start profiling state-controlled banks' activity and even merge some of them. Earlier or later that will lead to a system similar to the former USSR's spetsbanki (specialist state-owned banks for each broad field of activity) or to the system China currently has.

\section{Conclusions}

Revival of government banking in Russia started in 1999 and was fostered by the 2008 crisis. State-controlled banks now control over a half of all banking assets, and in some market segments their dominance is ever more pronounced (65 percent of household deposits, 63 percent of corporate loans). The number banks controlled by the state directly or indirectly reached 46 in 2009 but then fell to 40 in 2010, as a result of state divestment from second-tier players. The kind of financial intermediation that the government encourages and promotes through its banks is closer to development banking than classical commercial banking. In terms of public sector share and the direction of change Russia is more aligned with China or India but not the absolute majority of European emerging market countries.

One of the recent phenomena is gradual replacement of direct public ownership by indirect ownership and control via state-owned companies and banks and 'state corporations'. Around one-quarter of the public sector in banking has migrated outside direct control of the government. Indirectly-controlled banks enjoy asymmetric benefits of

8 Russian authorities learned this from the Chinese government that pursues much the same paradigm with regard to its core state-owned banks, actively luring external investors to buy minority equity stakes but continuing to use the banks for large scale policy lending. 
access to public funds but they rarely perform socially important functions on behalf of the government. Whereas indirect public ownership might have certain advantages in flexibility and efficiency, it deteriorates agency problem in the public sector. Corporate pyramids in the public sector may signal entrenchment of insiders against external investors and the state itself. Banks in this category are prone to opportunism of topmanagers and other influential insiders.

Policy lending on behalf of the government does not necessarily lead to poor profitability. Empirical research suggests that Russian state-controlled banks display efficiency comparable to domestic private banks. Our interpretation of this challenging finding is that in an environment where state-controlled banks dominate most product markets and enjoy non-competitive advantages, the nature of their earnings is rent rather than normal profit.

The context for a new wave of 'privatization' is rather similar to the situation in 1990s, only the assets involved are now much better capitalized, mostly by the state itself. Its results may be quite similar. In some cases we rather see entrenchment of the current blockholders than privatization proper. Direct government ownership is replaced by indirect ownership, or is transferred to affiliated parties and public sector institutions.

Like it or not, prevalence of state-controlled banks in Russia might be a sustainable long-term trend consistent with government policies of directed allocation of financial resources to politically important sectors and enterprises. Government banking fits best a state-controlled economy9 9

9 In the first half of 2010 state-controlled companies constituted around 60 percent of market capitalization of companies in RTS stock market index (Ekspert, No.19 (704), 17.05.2010, pp.45-47). 


\section{References}

Andrianova, Svetlana, Panicos Demetriades, and Anja Shortland (2009), "Is government ownership of banks really harmful to growth?" University of Leicester Working Paper No. 09/11, December 2009.

Anzoátegui, Diego, María Soledad Martínez Pería, and Martin Melecky (2010), "Banking sector competition in Russia". Policy Research Working Paper WPS5449, The World Bank.

Barth, James, Gerard Caprio, and Ross Levine (2000), "Banking systems around the globe: do regulation and ownership affect the performance and stability?". Policy Research Working Paper WPS 2325, The World Bank.

Bonin, John, Iftekhar Hasan, and Paul Wachtel (2005), "Bank performance, efficiency and ownership in transition countries", Journal of Banking and Finance 29(1): 3153.

CBR (2010), Banking Supervision Report 2009, Central Bank of the Russian Federation, Novosti Press, Moscow. http://www.cbr.ru/eng/publ/root_get_blob.asp?doc_id=8693

CBR (2011), Otchet o razvitii bankovskogo sektora i bankovskogo nadzora v 2010 godu (Banking Supervision Report 2010), Central Bank of the Russian Federation Novosti Press, Moscow. http://www.cbr.ru/eng/publ/root_get_blob.asp?doc_id=8693.

The Economist (2010), "Mutually assured existence", The Economist, 395 (8682), A special report on emerging markets, May 15th, 2010, pp.10-12.

Fan, Joseph, T.J. Wong, and Tianyu Zhang (2005), "The emergence of corporate pyramids in China" (February 2005). Available at SSRN: http://papers.ssrn.com/sol3/papers.cfm?abstract_id=686582.

Fidrmuc, Jarko and Philipp Süss (2011), "The outbreak of the Russian banking crisis", AUCO Czech Economic Review, 5, 1:46-64.

Fries, Steven, Damien Neven, Paul Seabright, and Anita Taci (2006), "Market entry, privatisation and bank performance in transition", Economics of Transition 14 (3):579-610.

Fungáčová, Zuzana and Tigran Poghosyan (2009), "Determinants of bank interest margins in Russia: Does bank ownership matter?" BOFIT Discussion Papers DP 22/2009, Bank of Finland, Helsinki.

Fungáčová, Zuzana, Laura Solanko, and Laurent Weill (2010), "Market power in the Russian banking industry". BOFIT Discussion Papers DP 3/2010, Bank of Finland, Helsinki.

Interfax (2010), Interfax-100. Rossiyskie banki, itogi 2009 goda (Russian Banks: 2009 Results), / Interfax - CEA, Moscow. 
Karas, Alexei, Koen Schoors, and Laurent Weill (2010), "Are private banks more efficient than public banks? Evidence from Russia", Economics of Transition, 18, $1: 209-244$.

Kirdina, Svetlana (2004), X- i Y-ekonomiki: institucionalny analiz (Economies of Xtype and Y-Type: Institutional Analysis), Nauka Publishers, Moscow.

Körner, Tobias and Isabel Schnabel (2010), "Public ownership of banks and economic growth - The role of heterogeneity". Preprints of the Max Planck Institute for Research on Collective Goods, 2010/41, Bonn, September 2010.

La Porta Rafael, Florencio López-de-Silanes, and Andrei Shleifer (2002), "Government ownership of banks", Journal of Finance 57, 1:265-301.

Lebedev, Vasily and Dmitry Sivakov (2011), "Obmanem statistiku" ("We shall deceive statistics"), $\quad$ Ekspert, $24(758): 32-42, \quad$ June 20. http://expert.ru/expert/2011/24/obmanem-statistiku/

OECD (2005), Corporate Governance of State-Owned Enterprises, Organisation for Economic Co-operation and Development, Paris.

Okhmatovskiy, Ilya (2009), "Performance implications of ties to the government and SOEs: A political embeddedness perspective", Journal of Management Studies, 47, 6:1020-1047.

Raiffeisenbank (2006), CEE Banking Sector Report 2006, Raiffeisen Zentralbank Österreich AG and Raiffeisen Centrobank AG. Vienna, September 2006. www.rzb.at/ceebankingreport2006

Raiffeisenbank (2010), CEE Banking Sector Report 2010, Raiffeisen Zentralbank Österreich AG and Raiffeisen Centrobank AG, Vienna, September 2010. www.rzb.at/ceebankingreport2010

RBK (2011), Krupneyshie banki Rossii v 2010 godu (Russia's Top Banks in 2010), RBC Ratings, March 2011, available online: http://rating.rbc.ru/article.shtml?2011/02/24/33178170

Schoors, Koen (2000), "A note on building a database on Russian banks: Fieldwork against the odds", Post-Communist Economies, 12, 2:241-249.

Sprenger, Carsten (2010), "State ownership in the Russian economy: Its magnitude, structure and governance problems", The Journal of the Institute of Public Enterprise, 33, 12:63-110, Hyderabad.

Vernikov, Andrei (2009), "Russian banking: The state makes a comeback?" BOFIT Discussion Papers DP 24/2009, Bank of Finland, Helsinki.

Vneshekonombank (2010), Annual Report 2009, Moscow: Vneshekonombank. 